Gellner, D.N. 2017, 'Afterword: So What Is the Anthropology About?' Religion and Society: Advances in Research 8: 203-209.

doi: 10.3167arrs.2017.080113

\title{
Afterword: So What Is the Anthropology of Buddhism About?
}

David N. Gellner, University of Oxford

\section{The role of anthropologists in the study of Buddhism}

It is simultaneously flattering and alarming to be represented as having written a key synthesis on the anthropology of Buddhism 27 years ago. ${ }^{1}$ The alarm arises not just from the passage of time but mainly from the fact-pointed out by Erick White in his contribution to this special section-that somehow the anthropology of Buddhism lost momentum shortly after that paper was written. Consequently, subsequent anthropology of Buddhism, White argues, has tended to reproduce the much earlier assumptions of the 1970s and 80 s rather than renewing and rethinking itself in the way that other sub-fields have done. In fact, quite a large amount of relevant work has been and is being done (not least on issues of gender ${ }^{2}$ ), but no one (to my knowledge) has yet attempted to synthesize it, perhaps because of the sheer size of the task. It may also be relevant that until recently many of those contributing to the field were based in Area Studies or Religious Studies departments, rather than in Anthropology. All this makes the efforts of Patrice Ladvig and Nicolas Sihlé, both in this collection and more widely, to shape and update the field, as well as to reflect critically on the terms in which it is defined, especially welcome.

Fields and sub-fields rise and fall for a variety of reasons. It was the supposedly flourishing state of the anthropology of Buddhism (alongside the even more flourishing anthropology of Islam) that stimulated efforts to develop the anthropology of Christianity (Robbins 2007: 5n1). There is an obvious irony that now the compliment is being returned: the evident excitement around the new anthropology of Christianity within anthropology more broadly is the inspiration for a renewed anthropology of Buddhism. ${ }^{3}$ To reconnect the anthropology of Buddhism to wider developments in

\footnotetext{
Acknowledgements: I thank Patrice Ladwig, Nicolas Sihlé, and Iselin Frydenlund for helpful comments on an earlier draft of this Afterword.

${ }^{1}$ Gellner (1990) was revised and reprinted as Ch. 2 in Gellner (2001).

2 The monograph on the Theravada movement in Nepal that I co-authored with Sarah LeVine (2005) should really have been given the title Rebuilding Buddhism, Empowering Women. No doubt far more would have been sold if it had been.

${ }^{3}$ As Ladwig and Sihlé note in their introduction, such initiatives inevitably invite the response that they are not really new. There certainly was excellent anthropological work on Christianity before the year 2000 (by J.D.Y. Peel, William Christian, and Mart Bax, to name only three). According to Hann (2007), what was new was in fact an overwhelming focus on Pentecostalism (in Africa and elsewhere). For a defence of the "newness" thesis, which argues that both Christianity and anthropology were undergoing changes around that time, see Robbins (2014).
} 
the discipline must be all to the good, as Caple does with the new interest in morality, Brac de la Perrière with materiality, Schober with the study of communalism and ethno-nationalism, Turek on emotion and charisma, and White with spirit possession. This collection of case studies provides a good overview of the range of work on Buddhism, both Mahāyāna and Theravāda, that is now being done. In the early days there was some anthropology of Mahāyāna Buddhism but there is far more today. The danger is that East Asian Buddhism-located as it is in nation-states where modernity and nationalism have been defined largely in opposition to Buddhism, rather than in terms of Buddhism - may be marginalized in a more self-consciously formulated and organized anthropology of Buddhism.

It is of course possible to take an extreme deconstructionist, empiricist, or micro-ethnographic approach and say that there is no problem. There is no single thing called Buddhism, either in the different places where "it" is practised or in the different periods when it has been followed. Therefore, in so far as Buddhist activists try to construct a single worldwide Buddhist movement, or when (for example) Japanese Buddhists think they are following the same "religion" as Sri Lankan Buddhists, they are suffering from false consciousness, or at least-following in Colonel Olcott's footsteps-are inventing an entirely new tradition.

On the other hand, we can accept that there is a single phenomenon, that there is a continuous historical series of links that join the various branches of the Buddhist world. If we do that, we may say that-even if there is no single defining essence present in every case of self-identified Buddhism - there is a bundle of traits that, in a very Buddhist way, are linked in a causal chain of dependent origination. If that is granted, then we have a series of historical and ethnographic complex phenomena, with associated structures of feeling, that it is legitimate to compare. It may turn out that they have more in common with each other than with similar non-Buddhist religious traditions. ${ }^{4}$ Since this is an empirical question to be settled by research, some of which has not yet been done, it may equally turn out that some forms of Buddhism are closer to local Shintoism or local Daoism or local Bön-often because they have existed for centuries side by side in mutual interaction) than they are to Buddhism in other countries or times.

It is tempting to claim that there are certain key symbols that are common to all forms of Buddhism - primarily the figure of the Buddha himself-and that everywhere this implies the value of renunciation, the benefits of gift-giving to the Sangha (however conceived), and commitment to the ideal of meditation and detachment. Turek's article reminds us just how central this ideal is and how important it is for it to be instantiated, in whatever form, wherever Buddhism exists. At the same time, concern for others, especially concern that they should be able to benefit from the supreme good of the Buddhist teachings is also pervasive, and certainly not an innovation of Mahāyāna Buddhism, as Gombrich (1971: Ch. 6) stressed long ago. Furthermore, detachment and non-violence are part and parcel of Buddhism's radical soteriological stance (perhaps Weber was not so wrong, after all) and this means that everywhere Buddhism is connected to death and the afterlife.

None the less, it is unlikely that there could ever be a single and final theory of Buddhism, any more than there can be a single and final explanation of gift-giving, marriage, or any other complex social phenomenon. Many anthropologists, sociologists, and historians have shown that, once human traditions acquire their own momentum as lived and embodied social practices, they can be turned to many purposes; in every generation they are continually reinterpreted and reworked to new

\footnotetext{
${ }^{4}$ Thus Carrithers (1990) compared Buddhism and Jainism as "enduring historical streams".
} 
ends. This is so even when there is remarkable continuity. That continuity, where it happens, is what really needs to be explained.

The role of anthropologists, then, is to take the difficult and often unpopular line that "it is not as simple as that": lives lived and the view from the bottom up, or from any specific place, are more complicated than the schemes proposed by economists, political scientists, development agencies and governments (Gellner 2009). There is a whole range of issues where anthropologists and Buddhist scholars have sought to undermine facile assumptions, e.g. that Buddhism is always and everywhere non-violent, that it is non-political, that it always stands for ascetic values and is opposed to the creation of wealth, that lay people are ignorant of Buddhist doctrine, that Buddhism is always rational and monks uninvolved in magic. ${ }^{5}$

This attempt to go deeper than conventional wisdom tends to mean, in the study of Islam, countering the conventional idea that Islam is one and homogeneous, and seeking to show its underlying diversity. In the study of Hinduism, the anthropological imperative may mean, on the contrary, emphasizing its unity in order to combat the conventional view that there is virtually nothing shared by all the various forms and traditions of Hinduism as practised (Gellner forthcoming). But what does anthropological contrariness mean in the case of Buddhism? The pluralism of all religion in practice is "especially true" of Buddhism, as Lewis (2014:1) recently reminded us: "...there never was any institution, single figure, or group of spiritual leaders that could prescribe conformity, or enforce it, across Asia or beyond."

\section{Buddhism, politics, and the state}

One area where anthropologists and other social scientists have made a considerable contribution is Buddhism's links to politics, ethnicity, nationalism, and the state (see, e.g., Madsen 2007; Mills 2003; Raghavan 2016; Seneviratne 1999; Walton 2016). Collective identities become pressing in the political context of democracy, electoral competition, censuses, and claims on resources. Whether a minority or a majority, Buddhists are no less susceptible to ethno-nationalism than anyone else, as Schober's contribution to this special section demonstrates. As she also shows, modern social media can inflame and exacerbate tensions. This is an area ripe for further systematic research.

The historian Adrian Hastings (1997) provided a very eloquent riposte to well-known modernist theories of nationalism, showing that national identities most certainly did exist before Hobsbawm's 'age of nationalism'. In all these cases, he argued, the presence of Christianity, and in particular the idea of a chosen people encapsulated in the Old Testament, provided the template, whereas Islam furnished a very different set of affordances. The case of Amhara nationalism in Ethiopia, going back as far as the sixth century, is highly significant in this respect, since it lies wholly outside European or Enlightenment influence (Hastings 1997: 150-1).

Some have argued that Theravāda Buddhism provides a similar strong template for protonationalism, i.e. national identity before the age of nationalism and colonialism. In other words,

\footnotetext{
${ }^{5}$ On Buddhism and violence, see, e.g., Jerryson and Juergensmeyer (2010) and Tikhonov and Brekke (2013), and cf. Frydenlund (2017); on Buddhism and politics, Kawanami (2016); on wealth, one could cite Reader and Tanabe (1998); on the supposed ignorance of (for example) Tibetans, despite being a storehouse of spirituality, see Moran (2004). As Caple shows in her article in this special section, Chinese followers of Buddhism share Moran's Western Buddhist prejudices against ordinary Tibetans. In their very different ways, Spiro (1970), Gombrich (1971), and Southwold (1983) all sought to contest the assumption that lay Buddhists were ignorant. For a more recent contribution on monks and magic, see McDaniel (2011).
} 
certain texts, such as the Mahāvamsa, were usable as a kind of charter for religiously infused nationalist feeling even before the modern era (Kemper 1991). Thus, Buddhist nationalism is not only a consequence of modernism, although the story of Buddhist modernism is undoubtedly deeply implicated in the rise of Sinhalese and other nationalisms. Buddhist nationalism could exist, to some extent, just as it could in Christian countries, even before the advent of colonialism and modern ideas of the nation-state. That, at any rate, is the claim. ${ }^{6}$

A preliminary effort to theorize the relation between Buddhism and politics was made by the late lan Harris (2016). He outlined three major modes of state-Buddhism relations (Buddhist authority over the political, fusion, political authority over Buddhism) and three sets of tactical accommodation (withdrawal, antagonistic symbiosis, and conflict). He offered this typology as a modest "attempt to impose some sort of order on an immensely complex territory" (2016: 9).

\section{Complexifying our understanding of Buddhism as a system}

Anthropologists do not stop at criticizing stereotypes, idées reçues, and common sense. They also seek to complexify notions of history, lay-monastic relations, ritual, spirit possession, etc. Sharing as they do the ideology of progress (or creative destruction) of the wider society, they also frequently turn their fire on the failings of their own disciplinary ancestors.

Theravāda studies have moved on and grown greatly in sophistication. There is clear evidence for this in the Theravāda Civilizations Project; but not only there. ${ }^{7}$ The relative backwardness of the anthropology of Mahāyāna Buddhism can be illustrated by the fact that we are some way from any equivalent in that area. Whatever one may think about the contentious issue of whether one can establish what the Buddha himself taught (especially about social and political arrangements), the question remains: how can a renunciatory doctrine provide the blueprint for a way of life, a civilizational model for the whole of a complex society, since societies must necessarily be concerned with their own reproduction, whether political, economic, or familial?

Brac de la Perrière's paper shows how alternative paths can and do still exist within Buddhism's hierarchical conceptual universe. Tambiah provided a classic illustration of that universe with his famous circular diagram divided into four quadrants (Tambiah 1970: 338). What is striking in Brac de la Perrière's case study is not only that knowledge of exorcism is a path to Buddhism (i.e. the powers won't work unless Buddhist precepts are followed), but that the Buddhist precepts are materialized on the adepts' bodies via tattoos.

White demonstrates that Theravāda has oracular forms of possession too (just like Mahāyāna); in so far as early observers adopted modernist or Protestant Buddhist assumptions about how Buddhism "was supposed to be", they simplified a complex reality. In fact much of the early work on Buddhism provided substantial and grounded material for more fluid, contested, hybrid readings of culture, and can easily be re-interpreted in that light, if so wished.

\footnotetext{
${ }^{6}$ Political scientists have noticed the pattern whereby Theravāda Buddhism provides strong support for nationalism, and (more recently) anti-Muslim nationalism, in Burma, Thailand, and Sri Lanka, if not further afield (Stepan 2014). The modernist thesis can still be saved, in modified form, by conceding that nationalism may have existed in pockets beforehand, as demonstrated by Hastings (1997), while reaffirming that it was only in the nineteenth and twentieth centuries that it began to be a compulsory and universal political principle.

${ }^{7}$ For the project, see Schober and Collins (2012). See also Skilling et al. (eds) (2012). On the phenomenology of Buddhist non-self, see Cook (2010).
} 


\section{Conclusion}

The foundational questions in the anthropology of Buddhism had to do with ritual, the status of the Buddha, and the legitimation of ritual and leadership roles. The early writings also focused on the question of identity: Just how Buddhist are these people? Or, less judgementally, what is it to be Buddhist? How do Buddhists themselves view "being a Buddhist"? And how does Buddhism relate to the non-Buddhist parts of their lives, since-in the classic formulation-"Buddhism in real life is accretive" (Gombrich 1971: 49)?

If people think they are Buddhist, if they call themselves Buddhist, and carry on a ritual, symbolic, and religiously experiential life that involves interacting with Buddhist figures in a Buddhist idiom, there is something comic about scholars endlessly worrying whether they are really Buddhist. This does not mean that, in the end, no judgement can be made. Brian Victoria (2010) has challenged scholars of Buddhism to do precisely that, in the context of Japanese Buddhists' advocacy of state violence. But a practitioner's partisan stance, as a starting point, is not likely to be conducive to the open-mindedness necessary for detailed and empathetic investigation.

In the final analysis I stand by my earlier conclusion that "the anthropology of Buddhism will have attained maturity only when it can focus equally on other questions and only when it can analyse and compare Buddhism in different contexts without immediately becoming embroiled in issues of identity and authenticity" (Gellner 2001: 59 [1990: 109]). By this yardstick I believe that the anthropology of Buddhism is a mature field. And it may well be that this maturity, already achieved in the 1990s, combined with the centrifugal tendencies of Area Studies, led to the dissipation of energy identified by White. Today, thanks to the efforts of Ladvig, Sihlé, Brac de la Perrière, and others, the anthropology of Buddhism today may be achieving more unity of purpose and more selfconsciousness than it has had for a long time.

I also stand by another conclusion from 1990-that the question of authenticity has always had meaning for Buddhists themselves. Moral judgements were not invented or imposed on Buddhism by colonialism. Evaluation is necessarily implied by the fact that Buddhism, from the outset, has always been deeply moral: it is and has always been an exemplary path and teaching asserting unequivocally that there is a right way to be human and that there are many wrong paths to be avoided.

\section{References}

Carrithers, Michael. 1990. "Jainism and Buddhism as Enduring Historical Streams" Journal of the Anthropological Society of Oxford 21 (2): 141-63.

Cook, Joanna. 2010. Meditation in Modern Buddhism: Renunciation and Change in Thai Monastic Life. Cambridge: Cambridge University Press.

Frydenlund, Iselin. 2017. "'Buddhism has Made Asia Mild': The Modernist Construction of Buddhism as Pacifism" in H. Havnevik, U. Hüsken, M. Teeuwen, V. Tikhonov, and K. Wellens (eds) Buddhist Modernities: Re-Inventing Tradition in the Globalizing Modern World, pp. 204-21. New York and London: Routledge.

Gellner, David N. 1990. "Introduction: What is the Anthropology of Buddhism About?" Journal of the Anthropological Society of Oxford 21 (2): 95-112. 
Gellner, David N. 2001. The Anthropology of Buddhism and Hinduism: Weberian Themes. Delhi: OUP.

Gellner, David N. 2009. "The Awkward Social Science? Anthropology on Schools, Elections, and Revolution in Nepal" JASO-online (NS) 1 (2): 115-40. (www.anthro.ox.ac.uk/jasoonline-2009-2010)

Gellner, David N. forthcoming. "Living with Polytropy and Hierarchy: The Anthropology of Hinduism" in S. Coleman and J. Robbins (eds) The Oxford Handbook of the Anthropology of Religion. OUP.

Gombrich, Richard F. 1971. Precept and Practice: Traditional Buddhism in the Rural Highlands of Ceylon. Oxford: OUP. (1991 reissue as Buddhist Precept and Practice, Delhi: Motilal Banarsidass.)

Hann, Chris. 2007. "The Anthropology of Christianity per se" Archives Européennes de Sociologie 48 (3): 391-418.

Harris, lan. 2016. 'Introduction to Buddhism and the Political Process: Patterns of Interaction' in Kawanami (ed.), pp. 1-10.

Hastings, Adrian 1997. The Construction of Nationhood: Ethnicity, Religion and Nationalism.

Cambridge: Cambridge University Press.

Jerryson, Michael K. and Mark Juergensmeyer (eds) 2010. Buddhist Warfare. Oxford and New York: OUP.

Kawanami, Hiroko. (ed.) 2016. Buddhism and the Political Process. Houndmills: Palgrave Macmillan.

Kemper, Steven. 1991. The Presence of the Past: Chronicles, Politics, and Culture in Sinhalese Life. Ithaca: Cornell University Press.

Lewis, Todd T. 2014. "Introduction" in T.T. Lewis (ed.) Buddhists: Understanding Buddhism Through the Lives of Practitioners. John Wiley and Sons.

LeVine, Sarah and David N. Gellner. 2005. Rebuilding Buddhism: The Theravada Movement in Twentieth-Century Nepal. Cambridge: Harvard University Press.

Madsen, Richard. 2007. Democracy's Dharma: Religious Renaissance and Political Development in Taiwan. Berkeley: University of California Press.

McDaniel, Justin T. 2011. The Lovelorn Ghost and the Magical Monk: Practicing Buddhism in Modern Thailand. New York: Columbia University Press.

Mills, Martin A. 2003. Identity, Ritual and State in Tibetan Buddhism: The Foundations of Authority in Gelukpa Monasticism. London: RoutledgeCurzon.

Moran, Peter. 2004. Buddhism Observed: Travelers, Exiles and Tibetan Dharma in Kathmandu. London: Routledge Curzon.

Raghavan, Suren. 2016. Buddhism Monks and the Politics of Lanka's Civil War: Ethnoreligious Nationalism of the Sinhala Sangha and Peacemaking in Sri Lanka, 1995-2010. Sheffield: Equinox.

Reader, Ian and G.J. Tanabe Jr. 1998. Practically Religious: Worldly Benefits and the Common Religion of Japan. Honolulu: University of Hawai'i Press.

Robbins, Joel. 2007. "Continuity Thinking and the Problem of Christian Culture: Belief, Time, and the Anthropology of Christianity" Current Anthropology 48 (1): 5-38. 
Robbins, Joel. 2014. "The Anthropology of Christianity: Unity, Diversity, New Directions: An Introduction to Supplement 10" Current Anthropology 55 (S10): S157-S171.

Schober, Juliane and Steven Collins 2012. "The Theravāda Civilizations Project: Future Directions in the Study of Buddhism in Southeast Asia" Contemporary Buddhism: An Interdisciplinary Journal 13(1): 157-66.

Seneviratne, H.L. 1999. The Work of Kings: The New Buddhism in Sri Lanka. Chicago: The University of Chicago Press.

Skilling, Peter, Jason A. Carbine, Claudio Cicuzza, and Santi Pakdeekham (eds) 2012. How Theravāda is Theravāda? Exploring Buddhist Identities. Chiang Mai: Silkworm Books.

Southwold, Martin. 1983. Buddhism in Life: The Anthropological Study of Religion and the Sinhalese Practice of Buddhism. Manchester: Manchester University Press.

Spiro, Melford E. 1970. Buddhism and Society: A Great Tradition and its Burmese Vicissitudes. Berkeley: University of California Press.

Stepan, Alfred. 2014. "The Theravada Buddhist Puzzle: Why Inclusionary Founding Doctrines and Exclusionary Contemporary Politics?" Rajni Kothari Lecture, CSDS, Delhi :

http://www.csds.in/events/theravada-buddhist-puzzle\# (consulted 14/5/17).

Tambiah, Stanley J. 1970. Buddhism and the Spirit Cults in Northeast Thailand. Cambridge: Cambridge University Press.

Tikhonov, Vladimir and Torkel Brekke (eds). 2013. Buddhism and Violence: Militarism and Buddhism in Modern Asia. New York: Routledge.

Victoria, Brian Daizen. 2010. "A Buddhological Critique of 'Soldier-Zen' in Wartime Japan" in M.K. Jerryson and M. Juergensmeyer (eds) Buddhist Warfare, pp. 105-30. Oxford: Oxford University Press.

Walton, M.J. 2016. Buddhism, Politics, and Political Thought in Myanmar. Cambridge: Cambridge University Press. 